\title{
Del caos al cosmos en los jardines de la Virreina: Ecos y espejos en la "Loa en las huertas" de sor Juana Inés de la Cruz
}

\author{
Leonardo Sancho Dobles \\ Universidad de Costa Rica, Costa Rica \\ leonardo.sancho.dobles@gmail.com \\ https://orcid.org/0000-0001-8707-3488
}

Recibido: 2 de marzo 2018

Aceptado: 30 de mayo 2018

\section{Resumen:}

Se ofrece un acercamiento a la "Loa en las huertas da donde fue a divertirse la excelentísima señora Condesa de Paredes, Marquesa de la Laguna". La breve pieza teatral utiliza personajes tomados de la mitología clásica y lleva a escena, en el plano estructural, un juego de repeticiones. Se explora la manera en la que funcionan estas repeticiones a nivel acústico, visual y simbólico.

Palabras clave: Loa; sor Juana Inés de la Cruz; espejo; eco; rima; estructura.

\section{From chaos to the cosmos in the gardens of the Virreina: Echoes and mirrors in the "Loa en las huertas" by Sor Juana Ines de la Cruz}

\section{Abstract}

It offers an approach to the "Loa en las huertas da donde fue a divertirse la excelentísima señora Condesa de Paredes, Marquesa de la Laguna" the short play uses characters taken from the classical mythology and takes to the stage in the structural plane a game of repetitions. The way in which these repetitions work at the acoustic, visual and symbolic level is explored.

Key words: Loa; sor Juana Inés de la Cruz; mirror; echo; rhyme; structure.

\section{(c) (i) (2) (2)}

La Revista Estudios es editada por la Universidad de Costa Rica y se distribuye bajo una Licencia Creative Commons Atribución-NoComercial-Compartirlgual 3.0 Costa Rica. Para más información envíe un mensaje a 
¿Qué proporción de distancia, el sonido modulando de mis hechos, hacer hizo cónsono lo destemplado?

Sor Juana Inés de la Cruz, Romance en reconocimiento a las inimitables plumas... vv. 57-60

El teatro breve de sor Juana Inés de la Cruz ha sido poco abordado por la crítica pues, en el universo de su producción literaria, los estudios, análisis, comentarios y exégesis sobre el género teatral se han concentrado mayormente en sus comedias y en el teatro sacro. A partir del momento en que las Obras Completas de la monja novohispana ven la luz hacia mediados del siglo $X X$ se ha segmentado el corpus sorjuanino y, a la vez, se ha establecido una jerarquía de la producción literaria de la monja novohispana que también se refleja en el estado del conocimiento alrededor del teatro breve al cual, cuantitativamente, se le ha dedicado un reducido margen de atención. Una mirada aparato crítico sobre este campo de estudio evidencia que en los últimos años solamente García Valdés (2004), Farré (2016 y 2017), Poot Herrera (2007), Olivares Zorrilla (2008), Rice (2013a y 2013b) y Rivera (2016) se han detenido en el estudio de estas piezas. Las trece loas que no corresponden al teatro sacro, conocidas como "las otras", ofrecen un amplio espectro de posibilidades para el estudio. Los motivos y temas, argumentos y estructuras, juegos verbales y escénicos, personajes y voces dan cuenta que también el teatro breve de sor Juana Inés de la Cruz es un tomo valioso y poco explorado de su universo de pensamiento.

En esta oportunidad se ofrece un acercamiento a la "Loa en las huertas a donde fue a divertirse la excelentísima señora Condesa de Paredes, Marquesa de la Laguna", de la escritora novohispana escrita y representada, según se ha establecido, entre 1680 y 1683, y fue publicada en el libro Inundación Castálida en

La Revista Estudios es editada por la Universidad de Costa Rica y se distribuye bajo una Licencia Creative Commons Atribución-NoComercial-CompartirIgual 3.0 Costa Rica. Para más información envíe un mensaje a revistaestudios.eeg@ucr.ac.cr. 


\section{Especial: Naturaleza amena y naturaleza agreste en las letras hispánicas} Madrid en el año $1689^{1}$ entre los folios 25 y 31 del tomo. El breve espectáculo teatral utiliza personajes tomados de la mitología clásica de occidente y lleva a escena en el plano estructural un juego de repeticiones acústicas y visuales que dejan traslucir a nivel de elaboración simbólica un complejo entramado de ecos y espejos. El objetivo de estas líneas consiste en explorar la manera en la que funcionan estas repeticiones a nivel acústico, visual y simbólico en esta pieza teatral breve de sor Juana Inés de la Cruz y se ofrecen algunas posibilidades de interpretación.

En la loa intervienen, según el orden de aparición, los personajes de la Música -no se especifica si se trata de un elemento coral como sí se hace en algunas didascalias en otras de las piezas breves- y las divinidades míticas Céfiro, Vertumno, Flora, Pomona y una Ninfa. El argumento es sencillo, al salir a escena la Música menciona que "La Reina de las luces" que ha descendido a la tierra y ha trocado "por sitial de flores / el solio de las estrellas" (vv. 3-4) y que las flores que emergen a su paso "al contacto de sus huellas" (v. 5) convocan a las demás para que presurosas salgan también a besar las plantas divinas: “¡Salid a priesa, a priesa, / flores, y besaréis sus plantas bellas!" (vv. 8-9), la imagen que se presenta es que al brotar los botones y abrirse las flores besan las plantas de la divinidad mientras camina. Al escuchar lo anterior el personaje Céfiro, quien ha aparecido por un lado del escenario, cree que se trata de su amada Flora y lo mismo ocurre con Vertumno, quien aparece por el otro de los lados, y por su parte piensa que las flores aclaman a su amada Pomona. Respectivamente ambos llaman a sus amadas para que acudan a escena y al salir ellas se percatan de que su adversaria también ha sido convocada, por lo que cada una se disgusta y las dos resuelven que sean sus amantes los que se batan a duelo para demostrar cuál de las dos es la verdadera divinidad de las flores. La contienda es interrumpida por la

\footnotetext{
${ }^{1}$ Título completo con el que sale a la luz es Inundación castálida de la única poetisa, musa décima, Soror Juana Inés de la Cruz... : que en varios metros, idiomas, y estilos, fertiliza varios assumptos; con elegantes, sutiles, claros, ingeniosos, útiles versos: para enseñanza, recreo, y admiración.
}

\section{(c) (i) (2)}

La Revista Estudios es editada por la Universidad de Costa Rica y se distribuye bajo una Licencia Creative Commons Atribución-NoComercial-CompartirIgual 3.0 Costa Rica. Para más información envíe un mensaje a revistaestudios.eeg@ucr.ac.cr. 
Especial: Naturaleza amena y naturaleza agreste en las letras hispánicas

Música y por la Ninfa quien en varias oportunidades pronuncian "iTened, parad, suspended los aceros!". La Ninfa aclara que ha sido delegada por la asamblea de las flores para detener la querella y que, por sugerencia del dios Apolo, les esclarece que las flores están haciendo referencia a la belleza y majestuosidad de la señora virreina quien es la verdadera majestad de los prados y jardines. Aclarado el malentendido los personajes cierran la pieza alabando las virtudes de la Condesa de Paredes y expresan sobre la virreina " ¡Que la Pomona más bella / y la Flora más hermosa / tenga hermosura de rosa, / pero duración de estrella!"

Al tomar en cuenta la mitografía, particularmente Ovidio Las metamorfosis y Fastos, las divinidades míticas presentes en la loa sorjuanina están vinculadas con el tópico del cambio y la transformación y los motivos de la naturaleza y la fecundidad. Céfiro dios del viento, fructificador y mensajero de la primavera, le susurra suavemente a la ninfa Cloris y la transforma en la diosa Flora a quien de entrega el dominio de las flores, los jardines y la primavera. Vertumno, por su parte, se relaciona con la noción de cambio y las transformaciones de la vegetación durante el paso de las estaciones, precede la maduración de los frutos. El joven se enamora de la inaccesible Pomona, la diosa de las frutas, los jardines $y$ las huertas $y$, transformado en anciana, la seduce mediante un relato en el que toma la metáfora de un olmo enlazado por una vid que representa el enlace amoroso. Como se puede observar las divinidades masculinas seleccionadas por la monja novohispana implican la seducción y el cambio, ya sea mediante el viento susurrado o el relato metafórico mientras que los personajes femeninos son divinidades míticas que se vinculan con la fertilidad, la renovación, los ciclos de vida, la floración, el cultivo y la recolección de los frutos.

En cuanto a los aspectos de forma, la pieza dramática echa mano de un considerable número de elementos estructurales y acústicos, sintácticos y fónicos los cuales evidentemente hacen referencia a la reiteración y al eco. En principio se observa que el esquema de la rima va de la asonancia hacia la consonancia, la

\section{(c) (i)(2) (2)}

La Revista Estudios es editada por la Universidad de Costa Rica y se distribuye bajo una Licencia Creative Commons Atribución-NoComercial-CompartirIgual 3.0 Costa Rica. Para más información envíe un mensaje a 
Especial: Naturaleza amena y naturaleza agreste en las letras hispánicas rima de la primera parte es asonante $e$-a que es suspendida por una pequeña serie de liras consonantes que dan pie a la rima asonante e-o, en clara alusión al eco, la cual abarca la mayor parte de los parlamentos, y culmina con una serie de rimas consonantes en estrofas redondillas. La utilización de la rima e-o no es casual en este caso, pues también los parlamentos que dicen los personajes masculinos y femeninos se encuentran organizados también en consonancia y responden a un esquema de correspondencias y similitudes:

\section{VERTUMNO}

Pues, si las flores aclaman, razón es que mi fineza ayude a su aclamación.

\section{CÉFIRO}

Si las flores lisonjean

su beldad, bien es que yo también la aplauda.

La correspondencia entre los parlamentos que pronuncian los personajes masculinos, por una parte, y los femeninos, por otra, también coincide con una relación de conformidad y repetición en el orden estructural de los elementos que en los que se compone cada parlamento.

FLORA

A tu voz amorosa, deudora a mi belleza, estima la fineza, 60 pues confiesa gustosa que yo solo del prado soy la diosa.

\section{(C) $(00$}

La Revista Estudios es editada por la Universidad de Costa Rica y se distribuye bajo una Licencia Creative Commons Atribución-NoComercial-CompartirIgual 3.0 Costa Rica. Para más información envíe un mensaje a 
POMONA

A tu amante cuidado, confiesa mi hermosura que el culto la asegura, confesando postrado, que solo mi poder preside al prado.

Como se puede observar en el manejo de los aspectos estructurales de la loa, la coincidencia fónica y sintáctica responde a un meticuloso manejo de esas herramientas por parte de la autora pues, a nivel de contenido, lo que se está poniendo de manifiesto es un error de interpretación y entendimiento, que se acentúa mediante la utilización de elementos acústicos y estructurales que remiten al eco, sensorialmente se busca producir una imagen de percepción auditiva. Los personajes de Céfiro y Vertumno interpretan de manera errada de la aclamación de las flores en la invocación inicial de la Música, pues estas no llaman a Flora y a Pomona, sino a la Reina que ha descendido de su trono celestial y se instaura en su reino terrenal. Esta confusión es la que lleva al conflicto, al enfrentamiento el cual se enfatiza mediante las reiteraciones y se resuelve mediante la intervención de la Ninfa, quien aclara el malentendido. Como recurso fónico hacia el final de la pieza se utiliza la rima consonante en los parlamentos de los personajes, particularmente acentuar que se ha resuelto el equívoco:

\section{VERTUMNO}

Y en señal de que todos, 305 ufanos y contentos, su dominio admitimos, repetid todos en sonoros ecos: ¡Que pues por Reina del Prado más bella Flora ha llegado, que a Flora de serlo priva!

\section{(c) (1) 8 ()}

La Revista Estudios es editada por la Universidad de Costa Rica y se distribuye bajo una Licencia Creative Commons Atribución-NoComercial-CompartirIgual 3.0 Costa Rica. Para más información envíe un mensaje a 
Especial: Naturaleza amena y naturaleza agreste en las letras hispánicas

MúsICA

¡Viva, viva, viva!

\section{CÉFIRO}

$Y_{¡}$ Pues para la corona

del prado, mejor Pomona

llegó, que el cetro reciba!

El eje argumental, tal y como ya se ha mencionado, se refleja con claridad en el plano fónico pues va desde la asonancia al inicio de la pieza, la disonancia en el momento en el que los personajes se enfrentan en el duelo y, finalmente, la consonancia cuando se aclara el error de interpretación. Al cerrar la loa con rima consonante se logra la armonía y el ritmo acústico entre las voces de los personajes y también acentúa la conformidad y el acuerdo de sus argumentos.

En cuanto a la propuesta escénica y a la sugerencia de imágenes visuales en la pieza, sor Juana Inés de la Cruz ofrece en esta loa algunas representaciones especulares. Desde que salen a la escena los personajes masculinos por cada uno de los lados, y sus respectivas amadas también, se evidencia el motivo de la repetición sensorial que atañe a la percepción visual de manera especular. Por otra parte las dualidades formadas por los personajes masculinos Céfiro y Vertumno, así como las divinidades Flora y Pomona, sugieren también un juego de reiteraciones simbólicas y plásticas. Estas coincidencias también se pueden observar en las parejas conformadas por Céfiro y Flora y Vertumno y Pomona:

POMONA

A tu aplauso agradecida...

[Aparte.] Mas... ¿No es Flora la que veo?

FLORA

Persuadida de tu voz...

[Aparte.] Pero... ¿No es Pomona ¡cielos! la que miro?

\section{(c) (†) (-)}

La Revista Estudios es editada por la Universidad de Costa Rica y se distribuye bajo una Licencia Creative Commons Atribución-NoComercial-CompartirIgual 3.0 Costa Rica. Para más información envíe un mensaje a 
CÉFIRO

Suspendida,

Alma del prado, divina Flora, te advierto...

\section{VERTUMNO}

Suspensa, Pomona hermosa, tu rara beldad contemplo:

¿Qué? ¿Te suspendes? ¿Qué tienes?

Ahora bien, si a nivel acústico y visual la pieza breve de sor Juana Inés de la Cruz pone de manifiesto un meticuloso y cuidado manejo de las imágenes fónicas y plásticas que se reflejan y repiten como ecos e imágenes especulares, es pertinente observar lo que, a partir de este entramado, esta loa propone a nivel simbólico también.

La presencia de las divinidades Flora y Pomona, relacionadas con los jardines, las flores, los cambios de estación, la fertilidad, el cultivo y la cosecha, como se mencionó con anterioridad, hacen que sea la imagen de la misma Virreina, Condesa de Paredes, la que se ve reflejada en ellas y, a su vez, ellas le devuelven su imagen, de acuerdo con el parlamento de la Ninfa:

vi resplandor más bello salir, que eran dos soles, 275

de quien, el mismo Sol aun no es reflejo:

la excelsa María Luisa, en cuyo hermoso cielo, lucen ámbar las rosas, fragante luz despiden los luceros.

Aqueste es el hermoso prodigio que, viniendo ya corona de las rosas, ya las rosas coronan su pie bello.

Aquesta es a quien deben ceder vuestro derechos de flores, pues le ceden ingenio Palas y hermosura Venus.

\section{(c) (i) (2)}

La Revista Estudios es editada por la Universidad de Costa Rica y se distribuye bajo una Licencia Creative Commons Atribución-NoComercial-CompartirIgual 3.0 Costa Rica. Para más información envíe un mensaje a 
En cuanto a la construcción hiperbólica en esta imagen y representación de la virreina se puede observar, además, que se incrementa con la incorporación de dos divinidades míticas canónicas Palas y Venus, con lo cual el discurso agrega belleza e inteligencia como atributos también de la Condesa de Paredes y enfatiza mucho más la construcción simbólica que se quiere ofrecer en la loa.

Según el parlamento de la Ninfa, es comprensible el mecanismo mediante la utilización de las metáforas celestiales y terrenales se le atribuyen ciertas cualidades a la virreina. Esta construcción metafórica en el plano semántico de la pieza acentúa la imagen que se quiere privilegiar de la virreina. En principio la "Reina de las luces" había descendido desde "el solio de las estrellas" hacia el espacio de "las florestas". Al utilizar las imágenes que hacen referencia a los astros y a las flores la pluma sorjuanina une dos espacios simbólicos y los entremezcla, así las estrellas serán las flores celestes y las flores son desplazadas a la imagen de estrellas terrenales así las rosas "lucen ámbar" y "fragante luz despiden los luceros". Este aspecto es recurrente en su poética ya que hay referencias también en una décima dedicada a la virreina ${ }^{2}$ y en uno de sus villancicos ${ }^{3}$, como se puede observar en la contienda verbal que entabla la primera voz en nombre de las estrellas y la segunda voz en nombre de las flores en las siguientes coplas en las que la voz 1 :

\section{Voz 1 .}

\section{Coplas}

Las estrellas es patente que María las honró tanto, que las adornó con sus ojos y su frente. Luego es claro y evidente que éstas fueron las más bellas.

\footnotetext{
${ }^{2}$ Celebra los años de la Excelentísima Señora Condesa de Paredes.

${ }^{3}$ Villancicos que se cantaron en la santa iglesia metropolitana de Méjico, en honor de María santísima, madre de Dios, en su Asunción triunfante, y se imprimieron, año de 1685.
} 
Coro 1.

¡Aquí de las estrellas!

Voz 2.

¿Qué flor en María no fue de las estrellas agravios, 20 desde el clavel de los labios a la azucena del pie? Luego más claro se ve que éstas fueron las mejores.

Coro 2.

¡Aquí de las flores!

25

Al hacer eco de la tradición clásica y cristiana, de la mitografía y de la literatura, y al utilizar recursos simbólicos como la epifanía y las advocaciones marianas, el verbo de sor Juana Inés de la Cruz inmortaliza a la virreina al atribuirle eternidad y belleza ${ }^{4}$. Si bien la Reina de las Flores ha trocado su espacio celestial por el terrenal, el discurso de la loa mediante la construcción metafórica y el empleo del eco y de la repetición de imágenes acústicas y visuales, eleva desde un espacio terreno hacia uno celeste a la virreina. La loa coloca a la virreina a un plano celestial al exaltar su belleza y aclamar por su eternidad.

¡Que la Pomona más bella

y la Flora más hermosa tenga hermosura de rosa, pero duración de estrella!

Finalmente, habría que considerar la datación de esta loa, la cual desde la edición de Alfonso Méndez Plancarte se ha establecido que fue escrita entre el año 1680, precisamente el año en que los virreyes condes de Paredes llegan a Nueva España, y 1683 cuando nace el primogénito del matrimonio. Como se puede observar la fecha de composición tampoco es casual pues antecede el nacimiento

\footnotetext{
${ }^{4}$ Este aspecto también es recurrente en la poética de sor Juana Inés de la Cruz, particularmente con los sonetos dedicados al motivo de la rosa, ver Sancho 2015

(c) (i) (-)

La Revista Estudios es editada por la Universidad de Costa Rica y se distribuye bajo una Licencia Creative Commons Atribución-NoComercial-CompartirIgual 3.0 Costa Rica. Para más información envíe un mensaje a revistaestudios.eeg@ucr.ac.cr.
} 
Especial: Naturaleza amena y naturaleza agreste en las letras hispánicas

del hijo de los virreyes de Nueva España. En este sentido empleo de las divinidades míticas que hacen referencia a la belleza y la fertilizad, al cambio y a la renovación, no es fortuito en este caso y, se puede constatar que esta loa se trata de algo mucho más que una pieza "humana, de festivo homenaje cortesano, o simplemente amistoso" (vii), como señalaba el mismo Méndez Plancarte hacia la mitad del siglo XX, y cuyo contenido está apenas por estudiarse y permitirá ampliar el espectro que enriquece el campo de conocimiento en la obra y en la producción dramática de sor Juana Inés de la Cruz.

\section{Bibliografía}

Farré Vidal, Judith, "Loa en las huertas a donde fue a divertirse la excelentísima condesa de Paredes". En: Carlos Mata Indurain (Coord), «Estos festejos de Alcides" Loas sacramentales y cortesanas del Siglo de Oro, New York, Idea/lgas, Colección Batihoja, pp. 259-278, 2017.

Farré Vidal, Judith, "Las loas de sor Juana, razones son finezas.", En Sara Poot Herrera y Antonio Cortijo Ocaña eds. "Sor Juana Inés de la Cruz_La construcción de lo femenino en su obra menor. Los mundos cortesano y festivo de loas y villancicos" Anthropos 243, (2016): 49-67.

García Valdéz, Celsa. "Una síntesis de las artes en el barroco hispánico: Las loas cortesanas de sor Juana." En Arellano Ignacio / Gogoy Eduardo eds. Temas del Barroco Hispánico, Madrid / Frankfurt: Iberoamericana / Vervuert, 2004: 107-127.

Hernández Araico, Susana. "Monarquía y montaje en las loas de Sor Juana." En Miguel Zugasti América sin nombre, número especial "Teatro breve virreinal" número 21 (2016): 59-71.

Méndez Plancarte, "Estudio liminar", Obras completas de Sor Juana Inés de la Cruz, tomo III, Autos y Loas. México: Fondo de Cultura Económica, 2001: vii-xcviii.

Poot Herrera, Sara. "La virreina se divierte "Loa en las huertas." En Judith Farré ed. Teatro y poder en la época de Carlos II. Fiestas en torno a reyes y virreyes, Madrid / Frankfurt: Iberoamericana / Vervuert, 2007: 237-255.

\section{(c) (i) (-)}

La Revista Estudios es editada por la Universidad de Costa Rica y se distribuye bajo una Licencia Creative Commons Atribución-NoComercial-CompartirIgual 3.0 Costa Rica. Para más información envíe un mensaje a revistaestudios.eeg@ucr.ac.cr. 
Poot Herrera, Sara. "Voces, ecos y caricias en las loas de sor Juana." En Sergio Fernández ed. Los empeños. Ensayos en homenaje a Sor Juana Inés de la Cruz. México: UNAM, 1995: 167-182.

Olivares Zorrilla, Rocío, "Las loas herméticas de sor Juana." Etiópicas 4, (2008): 166-187)

Ovidio. Fastos. Madrid: Gredos, 2001.

Rice, Robin Ann, "Estando ausente Carlos, /¿qué importa que las festivas voces le aplauden, si nada escucha?': las loas a los años del Rey Carlos II de Sor Juana Inés de la Cruz." Hipogrifo, revista de cultura y literatura del Siglo de Oro, vol. 1, no. 1, (2013): 57-86.

Rice, Robin Ann, "Filosofía, adulación y didáctica: las loas de Sor Juana dedicadas a los años de Carlos II." En: Lillian von der Walde, Mariel Reinoso eds. Virreinatos II, Colección Dossiers, México: Ed. Grupo Destiempos, 2013: 532-547.

Rivera, Octavio. "Teatro y poder en el virreinato de Nueva España: Las loas profanas de Sor Juana Inés de la Cruz." Anales del literatura española, 13, 1999: 127-140.

Rivera, Octavio. "Teatro breve, regalo de Sor Juana a los años de los condes de Galve." En Miguel Zugasti América sin nombre, número especial "Teatro breve virreinal" número 21 (2016): 117-128.

\section{(C) $(00$}

La Revista Estudios es editada por la Universidad de Costa Rica y se distribuye bajo una Licencia Creative Commons Atribución-NoComercial-CompartirIgual 3.0 Costa Rica. Para más información envíe un mensaje a 